\title{
A colaboração dos municípios na expansão do ensino secundário no estado de São Paulo (1930-1964)
}

The colaboration of the municipal governments in the expansion of secondary school education in the State of São Paulo (1930 - 1964)

La colaboración de los municipios en la expansión de la enseñanza secundaria en el estado de São Paulo (1930-1964)

\author{
Carlos Alberto Diniz ${ }^{1}$; Rosa Fátima de Souza ${ }^{2}$
}

\section{Resumo}

A contribuição dos municípios para a expansão do ensino secundário põe em discussão o intrincado jogo político que envolveu a democratização da educação média no Brasil. Este texto objetiva analisar as formas de atuação dos poderes públicos municipais no desenvolvimento da educação secundária no estado de São Paulo, no período de 1930 e 1964, quando ocorreu um expressivo crescimento da rede pública de ginásios e colégios. A análise recai inicialmente nos ginásios e escolas normais livres municipais criados na Primeira República. Em seguida, o texto examina a sistemática de contrapartida dos municípios exigida pelo Poder Executivo estadual para a criação de ginásios oficiais entre 1932 e 1947. Por último, o estudo problematiza a expansão dos ginásios públicos no Estado de São Paulo no período da redemocratização do país destacando o jogo político redefinido a partir das relações entre os deputados estaduais e as lideranças políticas locais.

Palavras-chaves: Ensino Secundário, Atuação dos Municípios na Educação Pública, Ginásios.

\footnotetext{
${ }^{1}$ Doutorado em Educação pela Universidade Estadual Paulista Júlio de Mesquita Filho. Diretor da Escola Técnica Estadual Sylvio de Mattos Carvalho do Centro Estadual de Educação Tecnológica Paula Souza. E-mail: caco.diniz.1979@gmail.com

${ }^{2}$ Doutorado em Educação pela Universidade de São Paulo, com estágio de pós-doutorado realizado na School of Education da University of Wisconsin (Madison, Estados Unidos), Professora titular da Universidade Estadual Paulista Júlio de Mesquita Filho e Professora do Programa de Pós-Graduação em Educação da Unesp de Marília. E-mail: rosa@fclar.unesp.br.
} 


\begin{abstract}
The contribution of the municipalities to the expansion of the secondary school education puts into discussion the intricated political game which involved the democratization of middle education in Brazil. This paper proposes to analyse the forms of acting of the municipal public power in the development of the secondary school education in the state of São Paulo from 1930 to 1964 when there was an expressive growth of the public junior and senior high schools. The analysis initially falls on the junior high schools and free municipal teachers training schools created by the First Republic in Brazil. Then, the paper goes on to examine the systematic compensatory measures demanded of the municipal governments by the state governments for, the latter, creating the junior high schools between 1932 to 1947 . Finally, the study problematizes the expansion of public junior high schools in the state of São Paulo in the redemocratization period of the country $(1945$ - 1964) highlighting the political game redefined from the relations between state deputies and the local political leaderships.
\end{abstract}

Key words: Secondary School Education (High schools), The roll of the municipal governments in public education, Junior High Schools.

\title{
Resumen
}

La contribución de los municipios a la expansión de la enseñanza secundaria pone en discusión el intrincado juego político que involucró la democratización de la educación media en Brasil. Este texto objetiva analizar las formas de actuación de los poderes públicos municipales en el desarrollo de la educación secundaria en el estado de São Paulo, en el período de 1930 y 1964, cuando ocurrió un expresivo crecimiento de la red pública de escuelas secundarias. El análisis recae inicialmente en las escuelas secundarias y en las escuelas normales libres municipales creadas en la Primera República. A continuación, el texto examina la sistemática de contrapartida de los municipios exigida por el Poder Ejecutivo estadual para la creación de escuelas secundarias publicas entre 1932 y 1947. Por último, el estudio problematiza la expansión de las escuelas secundarias publicas en el Estado de São Paulo en el período de la redemocratización del país destacando el juego político redefinido a partir de las relaciones entre los diputados estatales y los liderazgos políticos locales.

Palabras claves: Enseñanza Secundaria, Actuación de los Municipios en la Educación Pública, Escuelas Secundarias. 
As oportunidades de acesso dos jovens ao ensino secundário no estado de São Paulo alteraram-se significativamente a partir dos anos 30 do século XX. Até então, a educação popular, isto é, o ensino primário, fora o alvo privilegiado das políticas educacionais levadas a termo pelos governos do Estado cuja atuação se direcionou não apenas para a ampliação do número de escolas e matrículas, mas também para a modernização pedagógica e administrativa do aparelho de ensino envolvendo a criação de instituições modelares como os grupos escolares e as escolas-modelo e a reforma da Escola Normal. ${ }^{3}$ Nesse intenso processo de expansão da instrução primária concorreram também os municípios, ainda que de forma subsidiária e em menor número mantendo escolas primárias rurais, doando terrenos e prédios para a instalação de grupos escolares e até mesmo subsidiando as escolas privadas com recursos financeiros ${ }^{4}$ (SOUZA, 2015).

Em relação ao ensino secundário, a atuação do Estado foi bem menos significativa. Em 1930, havia apenas três ginásios estaduais em São Paulo - o da capital, o de Campinas e o de Ribeirão Preto, com matrícula de 1.443 alunos (SÃO PAULO, [1937], p. 261). ${ }^{5}$ O processo de expansão dos ginásios públicos intensificou-se entre 1930 e 1947 quando foram criados por lei 58 novos ginásios oficiais em diversos municípios, além de cursos fundamentais em escolas normais e no Instituto de Educação. Nas décadas seguintes, o crescimento foi extraordinário. Entre 14 de março de 1947 e 31 de janeiro de 1963, foram criados por atos legais 474 ginásios públicos e 121 colégios; um crescimento do secundário público sem precedentes no país.

Como atesta o estudo de Schwartzman et al (2000, p. 206), em 1939 havia 629 estabelecimentos de ensino secundário no Brasil, sendo 530 particulares e 99 públicos. Quase um terço das escolas estava no estado de São Paulo (196) que detinha também quase a metade das escolas públicas do país. Duas décadas depois, essa proeminência se mantinha. Em 1964, havia no Brasil 4.775 cursos de ensino secundário, 1.632 cursos no ensino público $(34,2 \%)$ e 3.143 no ensino particular $(65,2 \%)$, sendo 3.886 de primeiro ciclo - cursos ginasiais $(81,4 \%)$ e 889 cursos de $2^{\circ}$ ciclo - colegiais $(18,6 \%)$. O estado de São Paulo possuía a maior rede de ensino secundário do país (24\% dos cursos existentes) sendo 684 no ensino público $(59,6 \%)$ e 463 no ensino particular (40,4\%). Desses cursos, $77 \%$ eram do $1^{\circ}$ ciclo (ginasial) e o restante, $23 \%$ do $2^{\circ}$ ciclo (curso colegial) (BRASIL, 1964).

O que teria levado os interventores e governadores paulistas a investirem de tal maneira na educação secundária? Quais foram as forças políticas e sociais que atuaram nessa expansão? Em que medida os municípios paulistas contribuíram para esse extraordinário crescimento da rede pública de ensino secundário? Qual foi o papel do poder público municipal nesse processo de conversão do secundário de uma escola de elites para uma escola popular? Por ensino

\footnotetext{
${ }^{3}$ Em 1888, havia 130 escolas de primeiras letras na província de São Paulo atendendo 26.939 alunos matriculados (MENSAGEM..., 1888). Em 1930, o estado mantinha 3.362 estabelecimentos de ensino primário (309 grupos escolares, 205 escolas reunidas, 630 escolas isoladas urbanas e 2.218 escolas isoladas rurais) totalizando 356.292 alunos matriculados (SÃO PAULO, 1931). Estes dados são denotativos do expressivo investimento público em educação, embora, o crescimento das matrículas não tenha acompanhado o crescimento populacional e continuasse insuficiente para atender toda a população em idade escolar e para erradicar o analfabetismo. Ver: Souza (2009).

${ }^{4}$ Como mostra o estudo de Souza (2015), na transição do século XIX para o século XX, a atuação da Câmara Municipal de Campinas foi intensa no campo educacional com realizações em vários aspectos: a) na organização do ensino municipal, b) na colaboração com o governo estadual doando prédios, terrenos e subsídios e, c) pelo auxílio a instituições de assistência e aos particulares.

${ }^{5}$ Tudo indica que outros ginásios oficiais tenham sido criados por lei no estado de São Paulo durante a Primeira República, porém, não foram instalados. Por exemplo, em 1924, pela Lei n 2.017, de 26 de dezembro, foram criados os ginásios oficiais de Taubaté e Tatuí. De acordo com esta legislação, os dois ginásios deveriam ter o mesmo programa do ginásio da Capital e o de Campinas e seriam instalados "desde que as respectivas municipalidades ofereçam, prédio próprio para o seu funcionamento" (SÃO PAULO, 1924). O prédio do Ginásio de Tatuí começou a ser construído pela Prefeitura Municipal somente em 1930. Ver: https://issuu.com/oprogresso/docs/barao_pages
} 
secundário estamos considerando a modalidade de ensino que se consagrou no Brasil como etapa intermediária de escolarização, destinada à formação geral e desinteressada da juventude de caráter propedêutico.

A participação dos municípios na difusão do secundário tem sido pouco explorada na historiografia da educação brasileira demandando projetos temáticos de pesquisa de caráter abrangente e um grande número de monografias sobre a história de instituições escolares como ginásios, colégios, escolas normais e Institutos de Educação.

O objetivo deste artigo é analisar as formas de atuação dos poderes públicos municipais no desenvolvimento da educação secundária no estado de São Paulo, no período de 1930 e 1964, abrangendo assim, duas etapas no desenvolvimento do secundário público nesse estado: a primeira, de 1930 a 1947, período de prevalecimento dos interventores federais, trata do início da expansão dos ginásios oficiais pela articulação entre o Poder Executivo Estadual e a contrapartida dos municípios; a segunda, de 1947 a 1964, diz respeito ao período da redemocratização do país incidindo sobre as quatro legislaturas na Assembleia Legislativa quando ocorre uma rápida expansão do secundário público mediada pela intervenção dos deputados estaduais. ${ }^{6}$

O estudo fundamenta-se na Nova História Política, nos termos assinalados por René Rémond (2003), isto é, uma história das relações de poder em que sobressaí a participação na vida política. A história política da educação se volta para a compreensão das relações entre educação e Estado entendendo o poder e suas manifestações não só como soberania do Estado, mas como um assunto social que afeta os sujeitos particulares e coletivos. O papel do Estado na ampliação das oportunidades educacionais de nível secundário é compreendido nesse amplo espectro de fatores que associam as demandas sociais pela escolarização, a forma escolar moderna e as mudanças na organização do trabalho e na constituição do trabalhador nacional.

Na primeira seção, assinalamos alguns exemplos da atuação dos municípios paulistas na criação e manutenção de ginásios municipais e escolas normais livres durante a Primeira República. Na segunda, examinamos a primeira voga de criação de ginásios oficiais no período de 1930 a 1947, mapeando a colaboração dos municípios por meio do sistema de contrapartida adotado pelo Estado. Na terceira, analisamos a expansão dos ginásios públicos no Estado de São Paulo no período da redemocratização do país, mais delimitadamente entre 14 de março de 1947 e 31 de janeiro de 1963, ou seja, durante os governos de Adhemar de Barros (14 de março de 1947 a 31 de janeiro de 1951), Lucas Nogueira Garcez (31 de janeiro de 1951 a 31 de janeiro de 1955), Jânio Quadros (31 de janeiro de 1955 a 31 de janeiro de 1959) e Carlos Alberto Alves de Carvalho Pinto (31 de janeiro de 1959 a 31 de janeiro de 1963) destacando o papel proeminente desempenhado pelos deputados estaduais na expansão do secundário e as diversas estratégias adotadas pelas lideranças municipais para manterem e negociarem uma escola pública secundária para a sua respectiva localidade.

\section{Ginásios Municipais e Escolas Normais Livres}

Durante a Primeira República, a colaboração dos municípios para a promoção da instrução pública no estágio de São Paulo não se restringiu ao ensino primário, mas também, ao ensino profissional, secundário e normal. Para as finalidades deste estudo, cabe ressaltar a atuação das municipalidades na criação de ginásios e escolas normais livres municipais.

Como atesta o estudo de Souza (2014), em 1911, a Câmara Municipal de Araraquara, em reunião extraordinária, aprovou a construção de um prédio para a instalação de um ginásio concedendo para esse fim 25 contos de réis. Após a conclusão do edifício, a Câmara faria

\footnotetext{
${ }^{6}$ Este artigo apresenta resultados parciais do projeto de pesquisa intitulado "Ensino Secundário nos Estados de São Paulo, Minas Gerais e Rio de Janeiro: políticas governamentais e relações de poder (1945-1964)", coordenado pela Profa. Rosa Fátima de Souza, financiado pelo CNPq (Processo n 304684/2014-7).
} 
contato com pessoa idônea para instalar "por sua conta e com inteira autonomia um gymnasio equiparado ao Nacional." (Ata da Câmara Municipal de Araraquara, apud SOUZA, 2014).

Depois de concluídas as obras em 1913, a Câmara Municipal firmou contrato com os irmãos Lane que assumiram a direção do estabelecimento de ensino dando-lhe organização similar à da Escola Americana de São Paulo, mantida pelos presbiterianos. Dessa maneira, o ginásio passou a se denominar Araraquara College. Em 1919, devido à rescisão do contrato, foi fundada uma associação composta pelo prefeito municipal, vereadores e outros membros da elite política e econômica da cidade com o intuito de manter o ginásio. A denominada Associação Mackenzie de Araraquara, entrou em negociação com o Mackenzie College de São Paulo para que essa instituição mantivesse a direção pedagógica e técnica do estabelecimento de ensino. O Ginásio de Araraquara voltou a funcionar em 1920 com o nome de Escola Mackenzie de Araraquara adotando os métodos de ensino norte-americanos e oferecendo o curso primário, secundário e comercial em regime de internato e externato.

Em 1926, em decorrência das dificuldades atravessadas pela escola no sentido de se adaptar às novas determinações estabelecidas pela reforma federal do ensino secundário, Reforma Rocha Vaz (Decreto n. 16.782/A, de 13 de janeiro de 1925) a Associação Mackenzie de Araraquara entrou em acordo com a Câmara Municipal transferindo para o poder municipal os encargos com o ginásio. A partir de então, a escola passou a se denominar Gymnasio Municipal Mackenzie de Araraquara (SOUZA, 2014).

Em Sorocaba, segundo estudo de Gonçalves (2006), a Prefeitura Municipal concorreu para a manutenção do ensino secundário em vários momentos. ${ }^{7}$ Entre 1909 e 1911 funcionou o Ginásio Sorocabano subvencionado pela Câmara com um montante de 27 contos e 600 mil réis anuais. Posteriormente, na década de 1920, grupos rivais dentro do Partido Republicano Paulista (PRP) disputaram a criação de um ginásio na cidade. Opositores do Senador Vergueiro (antivergueiristas) apoiados pelo presidente do estado Júlio de Albuquerque Prestes defenderam a criação de um ginásio municipal que foi criado em 1927 pela Câmara Municipal, por proposta do vereador Gustavo Schreppel (Lei n. 204, de 26 de outubro de 1927). No ano seguinte, a Câmara voltou atrás e o ginásio iniciou o seu funcionamento como instituição privada sustentada com subvenção da Loja Maçônica Perseverança III e sediada no prédio da escola noturna gratuita mantida pela maçonaria. Em janeiro de 1929, assumiu a Câmara Municipal de Sorocaba o grupo antivergueirista e o prefeito municipal João Machado de Araújo, diretor do ginásio, propôs um projeto de restabelecimento da municipalização da escola (Lei n. 209, de 16 de janeiro).

Não podemos afirmar quantos ginásios municipais funcionaram no estado de São Paulo na Primeira República, contudo, as duas instituições mencionadas mostram como diferentes grupos sociais - as elites políticas, a igreja católica e protestante, a maçonaria, a iniciativa privada, entre outros, estiveram envolvidos na promoção do ensino secundário nos municípios. A ampliação das oportunidades educacionais constituiu-se em relevante e crescente demanda social no estado de São Paulo no início do século XX. Instituições educacionais públicas como o grupo escolar, a escola profissional, e especialmente a escola normal e o ginásio eram almejados pela população, pois, significavam prestígio para o município, uma vez que eram tidas como símbolos da modernidade e do progresso sócio cultural da localidade. Para obter tão acalentadas instituições de ensino, grupos locais interessados se mobilizaram para que a Câmara Municipal assumisse a manutenção de ginásios e pressionaram as autoridades políticas para solicitar, reivindicar e negociar a criação de escolas públicas oferecendo contrapartida em recursos financeiros, doação de terreno para construção de prédio para a escola ou oferecendo as instalações necessárias.

\footnotetext{
${ }^{7}$ De acordo com Sandano (2009), em 1887, a Câmara Municipal de Sorocaba criou o Lyceu Municipal que funcionou até 1892. Em Campinas, a Câmara Municipal subvencionou o Ginásio Culto à Ciências por vários anos. Ver Souza, 2015.
} 
Nota-se, portanto, diferentes estratégias utilizadas pelos grupos políticos locais para promoverem a educação secundária. Vale assinalar, nesse sentido, o modo pelo qual, no final da década de 1920, os municípios se envolveram na difusão das escolas normais livres tomadas como vias de acesso à escolaridade de nível médio e de ampliação do ensino secundário.

Em 1927, a Reforma do Ensino protagonizada por Amadeu Mendes, diretor geral da Instrução Pública do estado de São Paulo (Lei n. 2.269, de 31 de dezembro ${ }^{8}$ ), estabeleceu a equiparação entre as Escolas Normais Oficiais e as Escolas Normais Livres.

$\mathrm{Na}$ época, São Paulo contava com 10 Escolas Normais Oficiais instaladas nas seguintes cidades: duas na Capital e oito no interior: Itapetininga, Piracicaba, Campinas, Pirassununga, Guaratinguetá, Botucatu, São Carlos e Casa Branca. Eram denominadas "livres" as escolas normais privadas ou municipais cujos egressos podiam exercer o magistério somente em escolas primárias municipais ou privadas. A equiparação, portanto, deu a todos os normalistas direitos equivalentes ampliando, assim, as oportunidades de trabalho para o magistério primário devidamente habilitado. Como bem assinala Leila Maria Inoue, a equiparação visava formar professores a curto prazo para solucionar o problema de provimento das escolas isoladas nas localidades distantes do estado, sobretudo, nas zonas rurais. Além disso, "[...] foi uma tentativa de forçar os municípios a criarem Escolas Normais, pois, o estado alegava que não tinha condições para isso.” (2015, p. 56). A nova legislação foi vista por algumas lideranças municipais como uma oportunidade de atender demandas de grupos sociais locais que ansiavam por maiores níveis de escolaridade. De fato, entre 1928 e 1930 foram criadas 38 Escolas Normais Livres no estado de São Paulo sendo 10 municipais (26\%) localizadas em: Taquaritinga, Bauru, Mirassol, Taubaté, Santa Cruz do Rio Pardo, Lins, Itápolis, Sorocaba, São José dos Campos e Mogi das Cruzes.

Para que uma Escola Normal Livre fosse equiparada, ela deveria atender condições pedagógicas e materiais, entre elas:

Artigo 398. - São condições necessarias para a equiparação:

$6^{\circ}$ - possuir um patrimonio minimo de duzentos contos de réis, constituido por predios, immoveis ou apolices da divida publica.

7. ${ }^{\circ}$ - Quando as escolas forem fundadas pelas municipalidades, o patrimonio poderá, a juizo do Governo, ser constituido por títulos da Camara, depositados no Thesouro do Estado. (SÃO PAULO, 1929).

Para se compreender o modo pelo qual a expansão das escolas normais colaborou com a expansão do ensino secundário é preciso considerar as aproximações institucionais entre essas duas modalidades de escolas, particularmente os desdobramentos e mudanças graduais ocorridas no curso complementar. Considerado etapa preparatória para o curso profissional de formação de professores, o curso complementar transformou-se no início dos anos 30 do século XX em curso fundamental e este no ginasial. Além disso, em alguns municípios, a implantação da Escola Normal Livre foi o primeiro passo para a negociação com o Estado para a aquisição do ginásio.

Em Sorocaba, a criação da Escola Normal Livre ocorreu conjuntamente com o ginásio municipal, como asseveram Sandano (2009) e Almeida (2015). Em outras localidades, mesmo não assumindo a manutenção das escolas, algumas Câmaras Municipais apoiaram a iniciativa de particulares como em Araraquara, onde a Escola Normal Livre foi instalada em 1928, no prédio do Ginásio Municipal Mackenzie (ANTÔNIO; SOUZA, 2014). Em Franca, Wagner da Silva Teixeira (2000) encontrou em jornais da cidade artigos reivindicando a escola normal desde 1913. Assim que foi instituída a Reforma da Instrução Pública de 1927, professores e

\footnotetext{
${ }^{8}$ Vide SÃO PAULO, 1927.
} 
autoridades municipais articularam-se no início de 1928 para a criação da Escola Normal Livre. No salão nobre da Câmara Municipal reuniram-se o presidente da Câmara, coronel Francisco de Andrade Junqueira, "o major Torquato Caleiro, prefeito, Amaro Cruz inspetor de ensino, doutores Walfrido Maciel, João Marciano de Almeida, Ricardo Pinho, Roberto Tedesco, médicos, professores Agenor Aquino e Olívio Peixoto e advogados Luiz de Lima e Antônio Constantino." (TEIXEIRA, 2000, p. 72). Ainda segundo o autor, a Câmara Municipal de Franca destinou 200 mil réis exigidos para o funcionamento da escola e para a construção do prédio.

Os exemplos citados mostram o investimento dos municípios nos ginásios, escolas normais livres e escolas complementares visavam a ampliar a escolaridade da população atendendo especialmente frações da classe média e das elites locais. A despeito da educação popular (ensino primário), destinada às camadas populares, eram as instituições de nível médio que catalisavam a escola como dividendo político, isto é, como moeda de troca relevante nas disputas pelo poder das oligarquias regionais.

\section{A expansão dos ginásios oficiais e a contrapartida dos municípios (1932-1947)}

Em março de 1932, o Coronel Manoel Rabello, interventor federal iniciou o processo de expansão dos ginásios oficiais no estado de São Paulo criando quatro novos estabelecimentos de ensino nos municípios de Araraquara, Itu, Taubaté e Catanduva. ${ }^{9} \quad$ O que teria levado o interventor a tomar essa decisão e por que o privilegiamento dessas localidades? Somente minuciosas análises regionais poderão esclarecer o jogo político implicado na expansão dos ginásios estaduais no período entre 1930 e 1947. Nos limites deste artigo, cabe assinalarmos vestígios da colaboração dos municípios e a forma de atuação das elites locais.

Maria do Carmo Campello de Souza (2006) afirma que o período entre 1930 e 1945 deve ser considerado um turning point no federalismo brasileiro, isto é, nas relações entre o poder estatal central e as unidades federativas tendo em vista o processo de centralização do Estado. Como bem observa Codato, esse período político é contemporâneo de três processos simultâneos: "a limitação das prerrogativas das oligarquias estaduais, a concentração da capacidade decisória no nível federal e a difusão de uma ideologia tipicamente nacional." (2013, p. 190).

Em São Paulo, a instabilidade política foi notoriamente evidenciada nas inúmeras sucessões ao governo do estado - 16 interventores de 1930 a abril de 1938 e mais 6 até março de 1947. Grupos da oligarquia paulista estiveram em disputa permanente visando a manter a participação no governo. Como explica a bela análise de Codato (2008), os vários grupos da oligarquia paulista em disputa pela hegemonia política no estado nas décadas de 1930 e 1940 enfrentaram quatro situações distintas em relação à República Velha: inicialmente, o Partido Democrático (PD) se aliou aos tenentes contra as oligarquias tradicionais representadas pelo PRP - Partido Republicano Paulista apoiando a Revolução de 1930 que alçou Getúlio Dornelles Vargas ao poder. Porém, essa aliança durou pouco, uma vez que seis meses depois da revolução, o Partido Democrático se opôs aos tenentes em defesa "da ordem constitucional", da "autonomia" do estado e da insurreição armada contra a União em julho de 1932.

Com a derrota dos paulistas na Revolução Constitucionalista de 1932, a Chapa Única por São Paulo Unido manteve em 1933 a aliança entre os partidos oligárquicos, mas logo, na disputa pela Assembleia Constituinte estadual o PRP voltaria a se opor aos democráticos que apoiaram Armando de Sales Oliveira e se reuniram no Partido Constitucionalista que absorveu o extinto PD.

\footnotetext{
${ }^{9}$ Ver, respectivamente: SÃO PAULO, 1932a (Decreto n. 5.408, de 4 de março de 1932 - Araraquara), SÃO PAULO, 1932b (Decreto n. 5.424, de 5 de março de 1932 - Itu), SÃO PAULO, 1932c (Decreto n. 5.429, de 5 de março de 1932 -Taubaté), e SÃO PAULO, 1932d (Decreto n. 5.430, de 5 de março de 1932 - Catanduva).
} 
Com a instituição do Estado Novo em 1937 os "armandistas" perderam o poder e o comando do estado foi devolvido aos perrepistas por meio da nomeação de Adhemar de Barros pertencente à ala jovem do Partido Republicano Paulista. Em relação ao poder municipal, não se pode desconsiderar que a centralização política vigente durante a presidência de Getúlio Vargas (1930-1945) atingiu também os municípios, pois, as Câmaras foram fechadas e os interventores tinham a prerrogativa de nomear os prefeitos.

Como têm apontado vários autores (Souza, 2006, Carone, 1976, Codato, 2008, 2010) a centralização política e institucional levada a termo nesse período não eliminou as disputas internas das oligarquias, ao contrário, continuou prevalecendo nos municípios, o mandonismo, o clientelismo e os conflitos entre famílias tradicionais. Sem intermediação da Câmara Municipal, a luta pela escola tornou-se um empenho pessoal do prefeito e das lideranças políticas municipais.

Como bem observou Barbosa Lima Sobrinho no prefácio do pioneiro e hoje clássico Coronelismo, enxada e voto, de Victor Nunes Leal, "Para manter a liderança, o 'Coronel' sente a necessidade de se apresentar como campeão de melhoramentos locais, se não para contentar os amigos, pelo menos para silenciar os adversários. É o prestígio político de que desfruta que o habilita como advogado de interesses locais.” (1986, p. XV).

O caso da oficialização do Ginásio Municipal Mackenzie de Araraquara, em 1932, te apreender os possíveis meandros da negociação política entre lideranças locais e os governos do Estado. Na edição de 2 de fevereiro de 1932, o jornal O Imparcial notificou os caminhos percorridos para a transformação do ginásio municipal em ginásio estadual exaltando a atuação do prefeito municipal e outras lideranças do município:

[...] não podemos concluir essa notícia sem destacar novamente a estima pública, os nomes dos prezados cidadãos srs. Dr. Mário Arantes de Almeida prefeito municipal, José Maria Paixão e Dr. Christiano Infante Vieira, figuras de assignalado relevo na direção actual de Araraquara, e que, pela intelligencia e perseverança dos seus esforços conjugados, chegaram a alcançar a promissora Victoria dessa realização de tão inestimável proveito para a nossa cidade. Sobretudo o Sr. Jose Maria Paixão, cavalheiro dos mais dignos estimáveis em nosso município, pode dizer-se que foi o grande propugnador do gymnasio official de Araraquara, porque foi elle, como é geralmente sabido que se transportou para a capital de São Paulo, por longo tempo, expressamente com o intuito de batalhar pela criação do primeiro estabelecimento de ensino de nosso município, tendo a felicidade de ver os seus esforços amplamente coroados de êxito. (PELA CRIAÇÃO DO GYMNASIO OFFICIAL..., 1932 apud SOUZA, 2014).

O artigo permite inferir que a solicitação partiu de membros da elite local e foi negociada em São Paulo com o interventor Manoel Rabello ou quiçá com o Conselho Consultivo. Com exceção do ginásio de Araraquara, não se sabe se os demais ginásios criados por Manoel Rabello já funcionavam como municipais. Os termos exatos dessa negociação não são conhecidos, mas é provável que entre as muitas reivindicações e obras públicas solicitadas pelos prefeitos ao interventor, o ginásio figurasse como uma grande necessidade. Nos decretos de criação dos primeiros ginásios oficiais foi exigida a contrapartida dos municípios: prédio, mobiliário e gabinetes necessários, além do pagamento das despesas de manutenção do ginásio por dois anos. Ainda em 1932, foi criado pelo interventor José da Silva Gordo mais um ginásio 
oficial, em São José do Rio Preto ${ }^{10}$ com a mesma exigência de contrapartida da Prefeitura Municipal. Todos esses ginásios foram criados em conformidade com a reforma instituída por Francisco Campos em 1931, a qual ampliou a duração do secundário para sete anos de duração divididos em dois ciclos: o fundamental de cinco anos e o complementar de dois anos. A reforma instituiu também a frequência obrigatória às aulas e um rígido sistema de avaliação dos alunos, além de critérios rigorosos de inspeção e equiparação (SOUZA, 2008).

A contrapartida pode ter sido, portanto, uma alternativa de mão dupla, por um lado, viabilizava a expansão do secundário público demandado pela população, por outro lado, comprometia a colaboração das Prefeituras Municipais nesse empreendimento. A colaboração dos municípios paulistas na difusão do secundário foi normatizada em 1933 pelo Código de Educação do Estado de São Paulo Decreto n. 5.884, de 21 de abril elaborado na gestão de Fernando de Azevedo na Diretoria do Ensino. O Código fundamentado nos princípios da Escola Nova estabeleceu as bases gerais sobre as quais funcionaria o sistema de ensino paulista até os anos 60 do século XX. Em relação ao ensino secundário, ele instituiu as normas recém estabelecidas pela Reforma Francisco Campos, instituindo nos ginásios do Estado o curso fundamental e o complementar a ser organizado, progressivamente, "de acordo com as exigências do meio social e à medida que o permitirem as condições econômicas" (SOUZA, 2011). ${ }^{11}$ O Código estabeleceu também cursos ginasiais fundamentais, de cinco anos, anexos às Escolas Normais e Escolas de Comércio favorecendo a difusão do primeiro ciclo do secundário e prescreveu normas para o funcionamento dos ginásios municipais incentivando os municípios a criarem essa modalidade de escola oferecendo-lhes subsídios:

Art. 594. - O Govêrno poderá subvencionar por prazo nunca superior a 5 nos as municipalidades do Estado que mantiverem por sua conta estabelecimentos de ensino secundario, observadas as condições seguintes:

a) - funcionarem em edificio próprio municipal que tenha as condições higienicas e pedagógicas;

b) - terem mobiliario e material didático suficiente e inteiramente adequado ao ensino;

c) - terem diretoria e corpo docente idoneos;

d) - observarem a legislação estadual sobre os ginásios oficiais em tudo quanto lhes fôr aplicavel;

e) - terem pelo menos dois anos de funcionamento regular. (SÃO PAULO, 1933).

A subvenção constituía, portanto, uma aposta do governo do Estado na contribuição dos municípios na expansão do secundário público por meio da manutenção de ginásios municipais. No entanto, a precária receita das municipalidades consistia em um entrave para a responsabilização do poder local com escolas de nível médio. Entende-se, dessa maneira, a grande pressão das lideranças municipais para o Poder Executivo assumisse a expansão do secundário público.

Assim, os prefeitos viram na criação de ginásios municipais uma alternativa provisória para o atendimento das demandas locais e um expediente útil para negociar posteriormente com o governo estadual a oficialização (estadualização) do ginásio; portanto, o que realmente vigorou foi o expediente da contrapartida.

\footnotetext{
${ }^{10}$ Vide SÃO PAULO, 1932e.

${ }^{11}$ Em conformidade com o Código de Educação, o segundo ciclo do secundário, curso complementar, seria instalado nos ginásios oficiais do estado de São Paulo na seguinte ordem: 1) no ginásio da Capital, 2) nos ginásios de Campinas e Ribeirão Preto, 3) no ginásio de Tatuí, 4) em outras escolas ou cursos de ensino secundário.
} 
Entre 1932 e 1947, foram criados por lei 58 ginásios oficiais no estado de São Paulo. O maior número dessas escolas foi criado por Armando de Salles Oliveira (15 ginásios) seguido por Fernando de Souza Costa (10 ginásios) e José Carlos de Macedo Soares (20 ginásios), conforme pode ser verificado na tabela 1 .

Tabela 1 - Ginásios criados no Estado de São Paulo (1930-1947)

\begin{tabular}{|c|c|c|c|}
\hline Ano & Governante & $\begin{array}{c}\mathbf{N}^{\circ} \text { de } \\
\text { Ginásios } \\
\text { Criados } \\
\end{array}$ & Municípios atendidos \\
\hline \multirow{2}{*}{1932} & Manoel Rabelo & 4 & Araraquara, Itu, Taubaté e Catanduva \\
\hline & José da Silva Gordo* & 1 & São José do Rio Preto \\
\hline \multirow[t]{2}{*}{1934} & Armando de Salles Oliveira & 10 & $\begin{array}{l}\text { Araras, Santos, Franca, Tietê, Bauru, Jaboticabal, } \\
\text { Avaré, Faxina, São José do Rio Pardo e Sorocaba }\end{array}$ \\
\hline & Márcio Pereira Munhós* & 2 & São José do Rio Preto e Pirajú \\
\hline 1935 & Armando de Salles Oliveira & 5 & $\begin{array}{c}\text { Mogi das Cruzes, Amparo, São João da Boa } \\
\text { Vista, Penápolis e Itápolis }\end{array}$ \\
\hline \multirow[t]{2}{*}{1938} & $\begin{array}{c}\text { José Joaquim Cardoso de } \\
\text { Mello Neto } \\
\end{array}$ & 1 & Pirajuí \\
\hline & Adhemar Pereira de Barros & 1 & Rio Claro \\
\hline \multirow{2}{*}{1939} & Adhemar Pereira de Barros & 1 & Caçapava \\
\hline & José de Moura Rezende* & 1 & Itapira \\
\hline 1941 & Adhemar Pereira de Barros & 2 & Presidente Prudente e Marília \\
\hline 1945 & Fernando de Sousa Costa & 10 & $\begin{array}{l}\text { São José dos Campos, Limeira, Dois Córregos, } \\
\text { Capivari, Jacareí, Jaú, Cajuru, São Joaquim da } \\
\text { Barra, Pindamonhangaba e Mogi Mirim }\end{array}$ \\
\hline 1946 & $\begin{array}{l}\text { José Carlos de Macedo } \\
\text { Soares }\end{array}$ & 04 & Novo Horizonte, Cruzeiro, Pinhal, Igarapava \\
\hline 1947 & $\begin{array}{l}\text { José Carlos de Macedo } \\
\text { Soares }\end{array}$ & 16 & $\begin{array}{c}\text { Ibitinga, Barretos, São Roque, Presidente } \\
\text { Venceslau, Viradouro, Batatais, Matão, Iguape, } \\
\text { Caconde, Monte Alto, Santo André, Santa Rita } \\
\text { do Passa Quatro, São Simão, Birigui, Bragança } \\
\text { Paulista e Descalvado }\end{array}$ \\
\hline
\end{tabular}

* Governantes interinos

Fonte: Diário Oficial do Estado de São Paulo (2011) ${ }^{12}$ apud SOUZA; DINIZ, 2014, p. 226-227.

Por certo, a expansão dos ginásios oficiais compôs o capital político de Armando de Sales Oliveira. Vale lembrar que ele foi indicado por Getúlio Vargas como interventor federal de São Paulo em 1933 e, posteriormente, eleito governador pela Assembleia Legislativa lançando-se candidato à presidência da República em 1937 (CODATO, 2008). Fernando Costa, por sua vez, fazia parte da ala "autêntica" do Partido Republicano Paulista e José Carlos de Macedo Soares foi filiado ao Partido Constitucionalista e apoiou a queda do Estado Novo.

Na década de 1930, apesar da expansão dos ginásios oficiais, ainda predominava no estado de São Paulo as escolas secundárias de iniciativa privada. Em 1935, São Paulo contava com 115 ginásios particulares e municipais fiscalizados pelo governo federal, sendo 40 na Capital e 75 no interior (SÃO PAULO, [1937], p. 260). Em 1936, funcionaram 34 cursos secundários fundamentais mantidos pelo Estado: 24 dos ginásios, 9 das escolas normais oficiais e um do Instituto de Educação. A matrícula nesses cursos fundamentais foi igual a 9.412 alunos. (SÃO PAULO, [1938], p. 423). Havia no estado 43 escolas normais livres sendo 17 municipais

\footnotetext{
${ }^{12}$ Levantamento feito no Diário Oficial do Estado de São Paulo entre os meses de maio a junho de 2011. Disponível em: <http://www.imprensaoficial.sp.gov.br> ou <http://www.al.sp.gov.br/doc-e-informacao/ legislacao -pesquisa>.
} 
e 26 particulares. Sobre a intrínseca relação entre ginásios e escolas normais, o Chefe do Serviço de Ensino Secundário e Normal, professor Euzébio de Paula Marcondes, em relatório publicado no Anuário do Ensino do Estado de São Paulo 1936-1937, afirmou:

O ensino secundário é ministrado, em S. Paulo, de acordo com a lei federal, nos cursos fundamentaes de escolas de dois typos: os gymnasios, que só ministram ensino secundário, e as escolas normaes, que, além da educação secundária, formam professores primários, mediante dois anos de estudos pedagógicos, em continuação aos cinco annnos secundários. (SÃO PAULO, 1938, p. 423)

A sistemática de exigência de contrapartida dos municípios para a criação de ginásios oficiais consistia em medida política de atuação compartilhada entre o poder executivo estadual e o poder municipal. Adotando tal medida, o Estado comprometia os municípios a colaborarem na expansão do ensino público com custos consideráveis para a instalação dos estabelecimentos de ensino. Na maioria dos ginásios oficiais estabelecidos pelos governos do Estado de São Paulo no período de 1932 a 1947 consta a exigência de algum tipo de contrapartida dos municípios. Apenas três ginásios foram criados nesse período sem qualquer exigência de contrapartida: Pinhal, Barretos e Batatais (Respectivamente, SÃO PAULO, 1946, 1947 a e b). Para os ginásios criados entre 1932 e 1937 foi exigido a doação de prédio, mobiliário, gabinetes necessários ao funcionamento do ginásio e despesas de manutenção durante dois anos. A partir de 1938, a exigência maior passa a ser a doação de um terreno de 100 metros quadrados para a construção de um prédio para o funcionamento do estabelecimento criado pelo Estado e a cessão da Prefeitura para o Estado, sem quaisquer ônus para este, a título de empréstimo, do prédio e das instalações necessárias. Exigências específicas foram feitas para a Prefeitura Municipal de Itapira indicando nuanças nas negociações entre os interventores e prefeitos municipais para a criação de ginásios.

Artigo $5^{\circ}$ - Correrão por conta da Prefeitura Municipal de Itapira todas as despesas com a manutenção do Ginásio em 1940.

Parágrafo único- A partir de 1941 a referida Prefeitura contribuirá anualmente com a quantida de cincoenta contos de réis (50:000\$000) para as despesas com o funcionamento do estabelecimento. (SÃO PAULO, 1939b).

Em outros municípios, o empréstimo recaiu sobre as instalações de outras escolas, como, no caso de Mogi Mirim, cuja contrapartida para a criação do ginásio foi a cessão das instalações da escola comercial existente na localidade (SÃO PAULO, 1945d). O mesmo ocorreu na criação da Escola Normal e Ginásio Estadual de Cruzeiro cuja instalação ficou condicionada "à obrigação, por parte da Prefeitura Municipal local, de doar ao Estado um terreno de $100(\mathrm{cem})$ metros x 100 (cem) metros, destinados à construção de prédio, e o material escolar e didático, atualmente no Colégio Mantiqueira e Escola Normal de Cruzeiro, inclusive biblioteca, laboratório de física, gabinete de química e museu de história natural, conforme consta no processo n. 14.001/46 da Secretaria de Estado da Educação e Saúde Pública (Decretolei n. 16.076, de 12 de setembro de 1946) ${ }^{13}$.

A instalação e manutenção de ginásios municipais pode ter sido um expediente utilizado por alguns prefeitos com vistas à estadualização da escola, isto é, a sua transferência a curto e

\footnotetext{
${ }^{13}$ Vide SÃO PAULO, 1946a.
} 
médio prazo para o Estado. Na análise da legislação dos 58 ginásios criados entre 1932 e 1947, encontramos o registro de seis ginásios municipais: São João da Boa Vista, Caçapava, São José dos Campos, Jacareí, Pindamonhangaba e Matão. ${ }^{14}$ Por exemplo, na legislação de criação do Ginásio de São João da Boa Vista (Decreto n. 7.051, de 3 de abril de 1935), a justificativa de criação da escola pautou-se na pré-existência do ginásio municipal:

Considerando que a Prefeitura Municipal de São João da Bôa Vista já mantem um Gymnasio sob inspeção federal, satisfazendo assim os requisitos essenciais do art. 51, do decreto federal n. 21.241, de 4 de abril de 1932;

Considerando que ha conveniencia em se transferir esse Gymnasio para o

Estado;

Decreta:

Art. $1^{\circ}$ - Fica criado um Gymnasio Official em São João da Bôa Vista. $\S 1^{\circ}$ - Deverá ser feita ao Governo do Estado, sob a responsabilidade da respectiva Prefeitura Municipal, doação do predio, installações e do material didatico, em accôrdo com o art. $3 .^{\circ}$ paragrapho $4 .^{\circ}$, alinea 1 , do decreto federal n. 21.241, de 4 de abril de 1932.

$\S 2^{\circ}$ - Essa Prefeitura ficará ainda responsavel pela despesa com o funccionamento do Gymnasio, inclusive pagamento do pessoal, até 31 de dezembro do corrente anno. (SÃO PAULO, 1935a)

A doação do terreno, prédio e instalações do Ginásio Municipal existente em Matão foi exigida para a criação do Ginásio Estadual (Decreto-lei n. 16.871, de 10 de fevereiro de $1947^{15}$ ). A respeito da criação dessa escola, Diniz (2012) destacou que a atuação do prefeito daquele município junto ao Interventor Federal, Adhemar de Barros, se deu já na criação do Ginásio Municipal, amplamente noticiada pelo jornal A Comarca ${ }^{16}$, periódico que circula semanalmente até os dias de hoje em Matão e que foi utilizado como fonte primária nesse estudo na busca de evidências que comprovassem a relação União-Estado-Município que se dava a partir de então, e como essa realidade era apresentada à população através da imprensa escrita:

Em audiência que foi concedida ha dias ao Sr. Prefeito Municipal de Mattão pelo eminente Sr. Dr. Adhemar de Barros, foram lançadas as bases para fundação do nosso Gymnasio Municipal.

Eis um facto que bem demonstra o prestigio de que goza o governador matonense, e principalmente o interesse com que o ilustre Interventor paulista encara os problemas vitaes das populações do "hinterland", não as cercando de promessas esquivas, mas dando-lhes solução prompta e satisfactoria.

Prontificou-se ainda o Sr. Dr. Adhemar de Barros a fornecer por conta do Estado, ao Gymnasio matonense, todo o material necessário. Não

\footnotetext{
14 Vide SÃO PAULO, 1939, 1945a , 1945b, 1945c (Caçapava, São José dos Campos, Jacareí e Pindamonhangaba respectivamente).

${ }^{15}$ Vide SÃO PAULO, 1947.

${ }^{16}$ O jornal A Comarca foi criado em 04 de janeiro de 1925 pelos irmãos Ítalo e Augusto Ferreira, com o objetivo de "trabalhar pela criação da Comarca de Mattão", expresso no editorial de sua primeira edição publicado nessa data. Ressaltamos que o jornal analisado neste trabalho, mesmo dada a sua importância, não foi tomado como questão de pesquisa, mas como fonte privilegiada no que tange a reconstrução das representações ligadas aos atores políticos que estavam envolvidos na expansão do ensino secundário no interior paulista, e como elas eram apresentadas à sociedade local.
} 
fosse o grande chefe do Executivo bandeirante o estadista modelar que se tem revelado - laborioso, popular, dedicado amigo dos seus governados - e só esse gesto tão meritorio quanto expontaneo, bastaria para grangear-lher a sympathia dos mattonenses. Vêmos ahi reproduzida, neste acto do Sr. Dr. Adhemar de Barros, uma faceta característica das novas instituições que nos governam: regime de unidade, de colaboração, de congraçamento das cellulas da grande communidade brasileira.

Nesse confortador ambiente de comprehensão e de sympathias mutuas, tudo podemos esperar do Prefeito José Bartholomeu Ferreira, que tão bem sabe comprehender e levar a bom termo as aspirações dos seus munícipes. (GYMNASIO, 1940a apud DINIZ, 2012, p. 58).

Diniz (2012) ainda destacou em seu trabalho que, tendo a criação do Ginásio Municipal "Dr. Adhemar de Barros" sido concretizada, o governo estadual passou a subvencioná-lo, confirmando assim a política educacional preconizada no Código de Educação de 1933, revelando, por conseguinte, uma estreita relação entre o Executivo Municipal e o Executivo Estadual, conforme trecho da reportagem do jornal:

[...] obteve do grande governador paulista, a valiosa subvenção de 50:000\$000 annualmente.

Ficou dessa forma confirmado o elevado conceito de que goza o sr. Prefeito nas altas esferas governamentais, e especial atenção e simpathya que o sr. dr. Adhemar de Barros dedica á causa da instrucção. (GINÁSIO MUNICIPAL, 1941 apud DINIZ, 2012, p. 60).

Nessa direção, para Diniz (2012, p. 62):

Tudo leva a crer que o Prefeito havia negociado com o Interventor Federal a construção do prédio prevendo a possibilidade de transformálo em Ginásio Estadual num futuro bem próximo. Entretanto, a manutenção do Ginásio consistia em uma despesa onerosa para os cofres municipais, mesmo com a subvenção parcial dada pelo Estado. A estratégia tomada para transpor esse obstáculo culminou no Decretolei n. $76^{17}$ de 18 de abril de 1944 , que autorizava o arrendamento para a iniciativa privada do Ginásio Municipal pelo prazo de 10 anos, mediante concorrência pública [...].

Ao que tudo indica, a transferência da administração do Ginásio Municipal para a iniciativa privada seria uma forma do Executivo Municipal para assegurar o funcionamento desse estabelecimento de ensino. Considerando essa hipótese, devemos levar em conta o curto prazo decorrido de 02 anos e 07 meses - a partir do início da atuação do Colégio AngloLatino, cujo arredamento do Ginásio Municipal se deu pelo prazo de 10 anos - para a promulgação em 10 de fevereiro de 1947 do Decreto-lei estadual n. 16.871, incorporando o Ginásio Municipal ao Estado.

Pode-se dizer, portanto, que as condições impostas aos municípios pelo governo do Estado foi uma negociação individual, caso a caso. A instalação do Ginásio Estadual de Igarapava ficou condicionada à obrigação, por parte da Prefeitura Municipal, "de doar ao

\footnotetext{
${ }^{17}$ Decreto publicado no jornal A Comarca. Edição n. 966, de 23 de abril de 1944. Cf. DINIZ, 2012.
} 
Estado, o prédio, instalações didáticas e respectivo terreno, com cerca de $11.000,00 \mathrm{~m}^{2}$ (onze mil metros quadrados), onde funciona o Ginásio São Sebastião, daquela localidade, feitas as adaptações julgadas necessárias pelo Departamento de Educação." (Decreto-lei n. 16.668, de 31 de dezembro de $1946^{18}$ ).

As estratégias adotadas pelas municipalidades com vistas à difusão do secundário foram variadas. Em Itápolis, como ressalta Pavini (2017), a Câmara Municipal criou a Escola Normal Livre em regime de externato em 1929. Mais tarde, em 1934 a Prefeitura Municipal autorizou a adaptação do estabelecimento em regime de ginásio, nos moldes do Colégio Pedro II e passou a manter a escola com recursos do orçamento anual do município e da cobrança de taxas aos alunos. Em 1935, o ginásio foi oficializado pelo Estado (Decreto n. 7.105, de 10 de abril ${ }^{19}$ ) exigindo-se da Prefeitura doação do prédio, instalações e do material didático e pagamento de pessoal até 31 de dezembro de 1936.

Em Sorocaba, o Prefeito Municipal apoiou a iniciativa de criação do Ginásio Ciências e Letras em 1935, cedendo o prédio para a instalação do estabelecimento de ensino concebido para oferecer ensino secundário para operários. Contudo, conforme assinala Michel (2013), esta escola teve uma trajetória efêmera.

Nos anos 40 do século XX, as reformas do ensino secundário e normal estabeleceram as bases sobre as quais ocorreria a expansão do secundário no país. A Lei Orgânica do Ensino Secundário (Decreto-lei n. 4.244, de 9 de abril de $1942^{20}$ ), conhecida como Reforma Capanema, alterou a divisão do secundário em dois ciclos: o primeiro, denominado ginasial, compreendia um curso de quatro anos de duração; o segundo, o curso colegial de três anos de duração, compreendia dois cursos paralelos - o científico e o clássico. A Reforma normatizou também os tipos de estabelecimentos de ensino secundário: o Ginásio destinava-se a ministrar o primeiro ciclo (curso ginasial) e o Colégio, além do curso ginasial, os cursos de segundo ciclo (clássico e/ou científico). Em relação ao currículo, proeminência foi dada à formação humanística de caráter geral. Manteve-se o exame de admissão ao curso ginasial, um sistema rígido de avaliação e o sistema de equiparação.

No estado de São Paulo, em decorrência da reforma de 1942, novas prescrições para o secundário foram estabelecidas em 1945 (Decreto-lei n. 15.235, de 28 de novembro ${ }^{21}$ ) e a denominação para os estabelecimentos públicos de ensino secundário e normal foram assim definidos: Colégios Estaduais, Colégios Estaduais e Escolas Normais, Escola Caetano de Campos e Ginásio Estadual da Capital e Escolas Normais e Ginásios Estaduais. ${ }^{22}$

Os vínculos entre o ensino secundário e o normal estabelecidos na rede pública de educação paulista desde o final da década de 1920 foram reforçados nos anos 30 e 40 e tornouse o padrão característico da expansão do ensino médio até o final do século XX.

\footnotetext{
18 Vide SÃO PAULO, 1946 b.

${ }^{19}$ Vide SÃO PAULO, 1935 b.

20 Vide BRASIL, 1942.

${ }^{21}$ Vide SÃO PAULO, 1945e

${ }^{22}$ Lei Orgânica do Ensino Normal (Decreto-Lei n. 8.530, de 2 de janeiro de 1946): o ensino normal seria ministrado em dois ciclos: o primeiro destinado a regentes de ensino primário, com quatro anos de duração e o segundo, o curso de formação de professores primários, com três anos de duração. Previa ainda três tipos de estabelecimentos de ensino normal no país: curso normal regional, a escola normal e os institutos de educação. O ensino normal poderia oferecer cursos de especialização para professores primários e cursos de habilitação para administradores do primário. Os estabelecimentos de ensino normal deveriam manter escolas para prática de ensino (Cf. BRASIL, 1946).
} 


\section{O papel dos municípios na expansão dos ginásios oficiais no período de redemocratização}

Entre 14 de março de 1947 e 31 de janeiro de 1963, período de abrangência de quatro legislaturas no governo do estado de São Paulo, foram criados 474 ginásios públicos, indicando um crescimento quantitativo extremamente considerável, jamais visto na história da educação brasileira, sobretudo pela ação incisiva dos deputados estaduais, uma vez que a sistemática de criação de escolas instituída no final dos anos 40 retomou o critério da promulgação de lei aprovada na Assembleia Legislativa do Estado de São Paulo (ALESP). Como bem assinala Beisiegel (1964, p. 152-153):

Após a queda do Estado Novo, a criação de um ginásio estadual passou a depender da promulgação da lei aprovada na Assembléia Legislativa do Estado. As providências relacionadas à criação da escola, desde as primeiras solicitações locais até o início das atividades letivas do estabelecimento, implicam em um conjunto de iniciativas que movimenta numerosos agentes da política e da administração escolar. O deputado ocupa posição central nesse conjunto de iniciativas.

Merece destaque o fato de que para a expansão do secundário público paulista tenha concorrido diversos tipos de instituições, além dos ginásios e colégios, escolas normais e Institutos de Educação. Outra característica desse crescimento de estabelecimentos e matrículas foi a incidência da expansão no primeiro ciclo, isto é, no curso ginasial. Em 1962, havia 949 unidades de ensino secundário no estado de São Paulo, compreendendo 722 unidades de curso ginasial e 227 de curso colegial. No ginasial encontravam-se matriculados 246.392 alunos sendo 122.260 do sexo feminino. A rede pública atendia 54\% desses estudantes, isto é, 133.262 alunos. No colegial, o total de matriculados era de 37.937 dos quais 12.20 do sexo feminino ( $31 \%$ dos estudantes). A maior parte desses alunos, 22.215 (58,5\%) estudavam na rede pública. No ensino normal havia 267 unidades escolares com um total de 19.481 alunos, 10.515 matriculados em estabelecimentos mantidos pelo Estado atendendo 9.444 estudantes do sexo feminino (90\% do alunado normalista da rede pública). Em relação ao ensino superior, o estado contava em 1962 com 249 unidades escolares com matrícula igual a 29.071 estudantes (BRASIL, 1964, p. 24). A expansão dos Institutos de Educação também foi muito grande no estado de São Paulo, especialmente na década de 1950. De acordo com Labegalini (2009), entre 1933 e 1967, foram criados ou transformados de escolas já existentes, 120 instituições desse tipo.

No que diz respeito à expansão dos ginásios, Diniz (2017) procurou mapear a geopolítica inerente à criação e instalação desses estabelecimentos ginásios oficiais de ensino no Estado de São Paulo por entender que tal aspecto se impunha como elemento esclarecedor para uma melhor e mais ampla compreensão da ação dos deputados estaduais frente à questão da expansão do ensino secundário em âmbito paulista entre os anos de 1947 e 1963 . Em seu entendimento, a localização desse conjunto de escolas secundárias públicas revelou aspectos interessantes sobre as articulações políticas das elites locais com as lideranças no comando do Poder Executivo e do Poder Legislativo estadual, constituindo assim um campo político sob a perspectiva bourdieusiana, no qual as lideranças políticas em âmbito municipal também tinham um papel importante nessa expansão. Segundo este,

Quando as reivindicações pela escola ginasial partiam da população, especialmente dos municípios do interior e sem a interferência antecipada de deputados, estas eram submetidas geralmente à apreciação do prefeito e vereadores que, por sua vez, as repassavam para o legislativo estadual, em sua maioria, deputados correligionários. 
Em outros casos, a reivindicação pela criação da escola era encaminhada diretamente ao governador do Estado. Afinal, a criação do ginásio beneficiaria a população, mas também tanto os líderes locais quanto o deputado ou o governador que tivesse apresentado tal proposição na ALESP e, subsidiariamente, seus partidos políticos que supostamente obteriam cada vez mais prestígio, fortalecendo-se e ampliando seus redutos eleitorais. (DINIZ, 2017, p. 58-59).

Nesse jogo político, o Poder Executivo estadual exercia um papel imprescindível uma vez que este detinha a prerrogativa de promulgar leis que efetivavam a criação das escolas ginasiais, favorecendo-se e favorecendo seus aliados políticos. Concomitantemente, ao que tudo indica, também vetava projetos de lei que não lhe eram interessantes pelo viés político, procurando minimizar assim a influência de seus adversários. $\mathrm{Na}$ esfera legislativa, as comissões de Constituição e Justiça, de Educação, de Finanças e de Redação da ALESP tinham um papel proeminente, pois eram responsáveis por analisar e emitir parecer a respeito dos projetos de lei de criação de ginásios públicos.

A expansão dos ginásios públicos no Estado de São Paulo, ocorrida de maneira acelerada sem uma política educacional bem definida e pautada pela ausência de um diálogo permanente com o campo educacional, não representava apenas uma resposta à demanda das camadas médias e populares, mas também uma maneira destes atores políticos se manterem no poder. Desse modo, a criação de ginásios oficiais no Estado de São Paulo assumia proporções cada vez maiores, conforme indica o Gráfico 1, que colige todos os 474 ginásios criados ${ }^{23}$ entre 14 de março de 1947 e 31 de janeiro de 1963:

Gráfico 1: Ginásios oficiais criados no Estado de São Paulo (14/03/1947 a 31/01/1963)

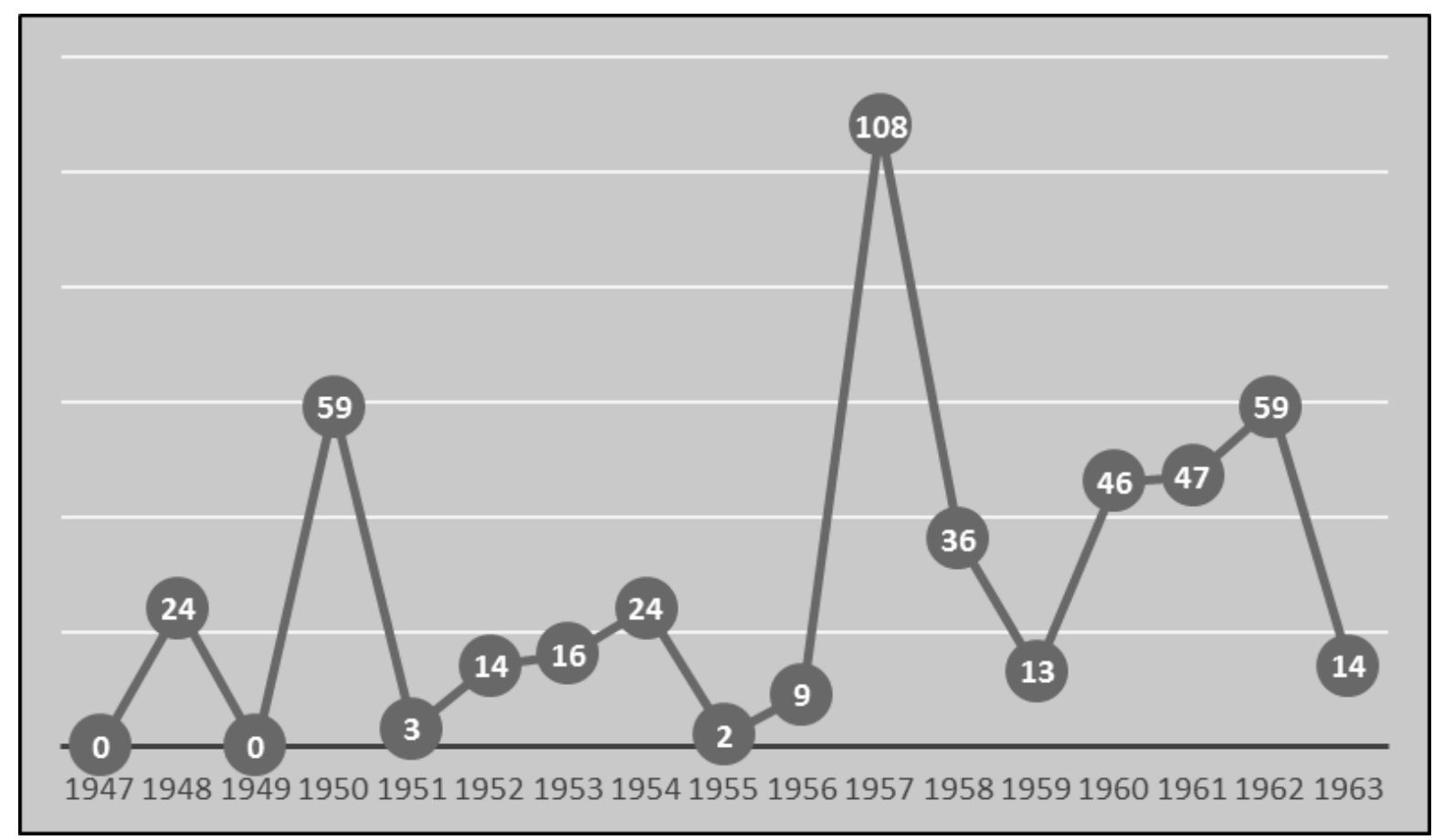

Fonte: DINIZ (2017, p. 77).

${ }^{23}$ Nesse montante se encontram contabilizados 346 ginásios criados por projetos de lei apresentados por deputados estaduais, 62 ginásios criados por projetos de lei de autoria da Comissão de Educação e Cultura da ALESP e 66 ginásios criados por proposição do Poder Executivo estadual. 
Tendo em vista que o crescimento dos ginásios não era um produto de uma política do Executivo ou do Legislativo, mas sim um produto de um jogo clientelista, o número de criações de ginásios aumentava totalmente de modo irregular, com picos nos anos de 1950 (último ano do governo de Adhemar de Barros), 1957 (penúltimo ano do governo de Jânio Quadros) e 1962 (último ano do governo de Carvalho Pinto), isto é, em épocas bem próximas das eleições, evidenciando assim o importante papel que a escola representava para a população em geral enquanto meio de acesso a melhores condições de vida. Sob o viés político, a escola compreendia um empreendimento com retorno significativo nas urnas.

Inversamente, no primeiro ano de cada novo governo é possível constatar a ausência ou um número reduzidíssimo de ginásios criados: em 1947, nenhum ginásio; em 1951, 03 ginásios; em 1955, 02 ginásios; e 03 ginásios em 1959 ${ }^{24}$. Diante desse fato, cabe um questionamento: tal incidência se dava pela necessidade de se conhecer a situação (financeira) do Estado deixada pelo seu antecessor? Ou o governador recém-empossado teria entendido que seria mais interessante fazer investimentos em momento próximo ao encerramento do seu mandato?

A criação de poucos ginásios no início de cada gestão se devia a um misto das duas vertentes apontadas, combinada com outros fatos que marcaram individualmente o começo de cada governo. Tal afirmação consiste no fato, por exemplo, do ex-governador Carvalho Pinto ter sido Secretário de Finanças na gestão anterior, ou seja, no governo de Jânio Quadros, o que nos leva a entender que o primeiro, ao suceder este último, detinha informações suficientes para manter o ritmo que vinha sendo empregado na expansão do ensino secundário, sem interrupções.

Por que Carvalho Pinto criou 46 ginásios oficiais no ano de 1960 que possivelmente poderiam ter sido criados em 1959? Muito provavelmente em função do apoio que este deu à candidatura de Jânio Quadros à Presidência da República no pleito que foi realizado no mês de outubro de 1960. Para isso, basta lembrar que dos 2.885 .441 votos nominais dos paulistas correspondentes a aproximadamente $25 \%$ dos votos nominais de todos o país -, 1.588 .593 votos foram para Jânio Quadros, ou seja, 55\% dos votos ${ }^{25}$.

Presumivelmente, não foi diferente a atuação de Adhemar de Barros que promulgou a criação de 59 ginásios no ano eleitoral de 1950, com o intuito de promover a eleição de seu sucessor ao comando do Executivo estadual, Lucas Nogueira Garcez, possuidor de pequena projeção no cenário político paulista.

Quanto ao legislativo, dada recorrentes mudanças de filiação partidária, que por sua vez podem ser vistas como uma das variáveis responsáveis pela redução, manutenção ou redução do tamanho da representação partidária no plenário, indica-nos que é num interregno eleitoral em que se acomodam as forças políticas e, do mesmo modo, elas se rearranjam com vistas às novas eleições, momento em que a legenda se sobrepõe, capitalizando para si o valor desse agente político como sendo dele (do partido) e, de acordo com os dividendos que ele traz para o partido, este o exclui, o mantém ou o promove ${ }^{26}$. Contudo, há de se observar que no caso brasileiro,

[...] a legislação encorajava a vida partidária, mas, ao mesmo tempo, incentivava o desenvolvimento de fortes lideranças individuais, criando um espaço propício ao confronto entre partidos e líderes, que acarretaria o enfraquecimento dos primeiros diante das grandes lideranças. (LIMA Jr., 1983, p. 40).

\footnotetext{
24 Todos os outros 10 ginásios foram criados no mês de janeiro de 1959, ou seja, na gestão de Jânio Quadros. Vale lembrar que, no período estudado, tanto as legislaturas quanto os mandatos do Poder Executivo eram iniciados e encerrados no dia 31 de janeiro a cada 04 anos.

${ }^{25}$ Vide BRASIL, 1963.

${ }^{26}$ Sobre partidos políticos, vide BOURDIEU, 2011, p. 204-205.
} 
Chamamos atenção para esse aspecto, pois, à realidade paulista, Diniz assinala que,

[...] é admissível inferir que durante os seus mandatos, no que concerne ao encaminhamento de projetos de lei de criação de ginásios oficiais, os deputados estaduais (e até mesmo os governadores) estavam mais associados a acordos com lideranças políticas locais dos seus redutos eleitorais e, em menor grau com a plataforma partidária, uma vez que não havia uma política educacional bem definida, mas sim um jogo político de interesses. Em outras palavras, ainda que o partido político pudesse ser visto como um reservatório de capital político, os deputados eram relativamente livres para negociar com as forças locais, independentemente dos ditames do partido, especialmente no intervalo entre as eleições. (2017, p. 82-83).

Logo, em âmbito municipal, as lideranças políticas locais se utilizavam de estratégias diversas em alinhamento aos Poderes Executivo e Legislativo estadual, para que a obtenção do ensino secundário público cada vez mais demandado pela população se efetivasse, como apresentaremos adiante.

A primeira dessas estratégias adotadas se refere às justificativas contidas nos projetos de lei apresentados no plenário da ALESP. Produzidas dentro de uma lógica de Estado por agentes políticos que se utilizavam de uma retórica argumentativa inerente do jogo político, os deputados (e também o Poder Executivo), recorriam às mais variadas situações encontradas nos municípios para justificar a necessidade da criação de ginásios públicos nas mais diversas localidades paulistas - além da representação do ginásio oficial enquanto símbolo de modernidade e possibilidade de ascensão social - notadamente:

a) o crescimento populacional em ritmo acelerado, sobretudo na capital, a exemplo dos projetos de lei n. 478/1951 e 436/1952 ${ }^{27}$, apresentados pelo deputado João Mendonça Falcão:

[...] Assim, instalar um Ginásio Estadual no operoso bairro do Parí é um ato de justiça para com seus moradores e um imperativo ao qual não podemos e não devemos fugir.

O bairro do Parí tem cêrca de 45.000 habitantes. É um bairro cujos moradores, na sua maioria, vive do seu trabalho diuturno e a quem os ginásios particulares são proibidos. Na verdade, ninguém ignora, como é obvio, que a instalação de um Ginásio Estadual acarreta despesas, mas será uma despesa compensadora e tudo que se fizer em benefício da educação do nosso povo, nunca será demais porque estaremos plantando para o futuro magnífico de nosso Estado. (SÃO PAULO, 1951a).

[...]

Assim, instalar um Ginásio Estadual no operoso Distrito de Itaquera é um ato de justiça para com seus moradores e um imperativo ao qual não podemos e não devemos fugir.

O bairro de Itaquera, é essencialmente proletário e não possue nenhum estabelecimento de ensino secundário. Os seus moradores representados pelos srs. Sho Yoshioka, Matajiro Yamagushi, e Dr. Oscar Americano, estão dispostos a colaborar, até financeiramente,

\footnotetext{
${ }^{27}$ Vide SÃO PAULO, 1951a; SÃO PAULO, 1952a.
} 
para a construção e instalação do Ginásio no citado Bairro. Assim, com apoio e colaboração espontânea do povo de Itaquera, espero obter das autoridades competentes o apoio necessário para ver satisfeita essa pretenção do laborioso povo de Itaquera. (SÃO PAULO, 1952a).

b) a dificuldade em transportar alunos para outros municípios próximos que tinham estabelecimentos secundaristas, a exemplo da justificativa apresentada no projeto de lei de criação de um ginásio em Urupês:

O município de Urupês dista 40 quilômetros das cidades de Catanduva e Novo Horizonte, localidades em que se servem os moços deste município para prosseguirem seus estudos.

Esses alunos para frequentarem os ginásios dessas localidades são obrigados a saírem de Urupês às 4 horas da manhã para as aulas que começam às 7, e regressam à casa para o almoço às 13 horas.

A criação do ginásio de Urupês justifica-se, por contar aquele município grande número de alunos frequentando ginásio das cidades vizinhas, acima citada, contendo, ainda, com dois grupos escolares com alunos suficientes para sustentarem a efetivação desta medida. (SÃO PAULO, 1952d).

c) os municípios recém-criados, que eram até então distritos de outros municípios ou, entre outros casos, distritos que se encontravam em vias de se emanciparem politicamente, como é o caso dos projetos de lei de criação de ginásios nos municípios de Auriflama e Vinhedo:

Constitui Auriflama um município novo, de vez que foi criado pela Lei n. 2.456, de 30 de setembro de 1953. Entretanto, o seu crescente desenvolvimento asseguram-lhe um futuro promissor.

Em face do seu progresso, pois, o município de Auriflama merece ser contemplado com um estabelecimento secundário de $1^{\circ}$ ciclo. Este é o objetivo do presente projeto, cuja aprovação virá tornar realidade as aspirações da mocidade estudiosa da cidade. (SÃO PAULO, 1956a).

Com menos de dez anos de vida autônoma, o Município de Vinhedo demonstra o progresso alcançado nesse breve período, graças à operosidade de sua população e ao zelo de suas autoridades, [...].

Ascende a quase 200 o número de jovens de ambos os sexos que, por falta de um ginásio local, fazem seus estudos secundários em localidades vizinhas.

Tais dados, além das condições urbanas de Vinhedo, que são as melhores de todos os pontos de vista, justificam a criação de um ginásio oficial naquela cidade, justa aspiração de sua população que o presente projeto de lei encampa e que seu autor oferece à alta consideração desta ilustre Assembléia. (SÃO PAULO, 1956b).

d) a "devolução" das contribuições e/ou impostos pagos pelos municípios ao Estado na forma de benfeitorias, ou ainda o "surto" de desenvolvimento pelo qual passam os municípios do interior, como apontam as justificativas elencadas nas proposituras para criação de ginásios em Taiúva, São José da Bela Vista e Juquiá: 
A oportunidade da medida preconizada é fato que não pode restar margem para dúvidas, pois, o município de Taiúva encontra-se entre aqueles que maior surto de progresso tem evidenciado no interior do nosso Estado.

A quantidade de alunos desse município, habilitados para cursar o ensino secundário, representa um número bastante expressivo.

Nada mais justo pois, concretizar-se a aspiração, bastante cabível, dos laboriosos munícipes de Taiúva, aprovando-se o projeto em questão. (SÃO PAULO, 1957a).

São José da Bela Vista é município que, por seu elevado grau de desenvolvimento, comporta perfeitamente a criação de um estabelecimento secundário de $1^{\circ}$ ciclo. [...]

Ora, não é justo que um município, que contribui permanentemente com quantias elevadas ao Estado, veja sua juventude sacrificar-se culturalmente por falta de escolas adequadas. Deve o Estado socorrê-lo. (SÃO PAULO, $1957 b)$.

Apresenta o município de Juquiá um índice de relevante importância pois no quinquênio último concluíram o curso primário nada menos que 904 alunos, estabelecendo a média anual de 180 alunos concluintes dos cursos primários existentes no município, cuja população orça atualmente em 7.000 habitantes. (SÃO PAULO, 1957e).

Cabe aqui destacar que as justificativas contidas em vários projetos de lei vinham acompanhadas de abaixo-assinados preenchidos por munícipes, importante instrumento de reivindicação que expressava a vontade popular, a exemplo do contido na documentação do projeto de lei n. 1.081/1952 que objetivava a criação de um ginásio no município de Colina:

Os abaixo-assinados, moradores nesta cidade, fazendeiros, criadores e agricultores neste Município, vêm dirigir à Vossa Excelência a presente representação, por intermédio do Prefeito deste Município, [...], apelando para o vosso elevado espírito de governo no sentido de ser criado e instalado nesta cidade um ginásio do Estado. Tomamos a liberdade de expor a Vossa Excelência, que a nossa cidade, cujo meio comporta perfeitamente a instalação e funcionamento de um estabelecimento desse gênero, desde há muito se ressente dessa falta e agora lançamos este apelo à Vossa Excelência convictos de sermos atendidos, o que virá satisfazer tão justa aspiração do povo colinense que vos ficará sumamente grato. (SÃO PAULO, 1952c).

Por outro lado, tal documento pode ter sido elaborado a partir de sugestão do próprio deputado, autor deste projeto, em acordo com os líderes políticos locais para evidenciar a importância que tal reivindicação representava em âmbito municipal, uma vez que "as pequenas cidades do interior encontraram no deputado estadual um agente situado em posição privilegiada para o encaminhamento de suas reivindicações no campo da educação secundária” (BEISIEGEL, 1964, p. 157). Ademais, há que se afirmar que a população valorizava a execução de melhorias na infraestrutura nas localidades onde residia e, desse modo, pressionava o poder local (prefeito e/ou vereadores) para que atuasse em favor dos interesses da população. Esses, por sua vez, se viam compelidos a buscar apoio na esfera estadual, a partir dos deputados, firmando e/ou fortalecendo alianças políticas com vistas a garantir o prestígio político para ambos. 
Além de abaixo-assinados, outros projetos de lei que foram analisados por Diniz (2017) vinham acompanhados das justificativas apresentadas de ofícios de líderes políticos locais, relatórios contendo dados estatísticos das localidades, fotografias e plantas prediais, com o intuito particular de evidenciar a capacidade dos municípios, sobretudo os do interior, em atender a contrapartida material exigida pelo Estado para que tais solicitações fossem deferidas, mas também para indicar os inúmeros benefícios que a implantação do curso ginasial proporcionaria para tais comunidades.

No que tange a contrapartida material por parte dos municípios do interior, que elencamos como sendo a segunda estratégia adotada nesse período, e que é decisivamente a mais importante no processo de expansão do ensino secundário no Estado de São Paulo, evidenciando a manutenção do mecanismo adotado à época dos interventores federais de contrapartida dos municípios no processo de estadualização do ensino secundário, ainda que aplicada de maneira desigual, pois esta era imposta apenas aos municípios interioranos como condição para a obtenção do seu ginásio público.

Nessa direção, é importante salientar que a contrapartida material se tornava para os municípios do interior quase como uma obrigatoriedade, a ponto de ser indicada já no momento da apresentação do projeto de lei, em parágrafo próprio, como por exemplo, o projeto de lei de criação de um ginásio em Jales:

Projeto de Lei n. 1.366, de 1951.

Cria um ginásio estadual em Jales.

Artigo $1^{\circ}$ - Fica criado, na sede do município de Jales, um ginásio estadual.

Parágrafo único - A instalação do ginásio ora criado fica condicionada à doação do prédio por parte do município de Jales.

[...]

Sala das Sessões, 13 de dezembro de 1951. (SÃO PAULO, 1951c).

Quando não anunciada a contrapartida, não raro era o veto do governador, a exemplo do caso de Colina:

Senhor Presidente,

Com relação ao Projeto de Lei n. 1.081, de 1952, que trata da criação de um ginásio estadual na cidade de Colina, - tenho a honra de comunicar a Vossa Excelência que os órgãos técnicos da Secretaria de Estados dos Negócios da Educação, ouvidos sobre o assunto, opinaram pela transferência, para época mais oportuna, da efetivação desta medida de ordem legislativa.

Inúmeras são as propostas de criação de ginásios, colégios e escolas normais em tramitação na Assembléia Legislativa. Não pode o Estado, assoberbado com tantos compromissos de natureza material e técnica no setor da educação secundária, assumir o encargo de todas estas novas proposições, razão pela qual, embora reconhecendo o elevado espírito público que as ditou, se vê o Executivo na contingência de limitar ao mínimo possível os projetos de lei que devam ser acolhidos, no interesse do próprio ensino.

Em consequência, tenho verificado, tanto na Capital como no interior, quais os núcleos que deveriam ter solucionados, preferencialmente, os seus problemas de educação secundária, o Poder Executivo sugere à nobre Assembléia Legislativa se transfira para época mais oportuna, a criação do que trata este projeto de lei. [...]

LUCAS NOGUEIRA GARCEZ - Governador do Estado (SÃO PAULO, 1952c). 
Porém, logo no ano seguinte (1953), o governador Lucas Nogueira Garcez voltou atrás em sua decisão, condicionando a criação do ginásio em Colina mediante contrapartida do município:

Em aditamento ao meu ofício n. 19449, de 26 de novembro de 1952, tenho a honra de comunicar a Vossa Excelência, para conhecimento dessa augusta Assembléia Legislativa, que o Poder Executivo está de pleno acordo com o Projeto de Lei n. 1.081/52, de autoria do Deputado Amaral Furlan, contanto que o Município, ou quem de direito, doe ao Estado terreno e prédio adequados ao funcionamento do novo ginásio, que deverá ser instalado somente no ano de 1955. (SÃO PAULO, 1952c).

Entretanto, a contrapartida material não foi exigida para alguns municípios do interior paulista no ato da criação dos seus ginásios, mas foi necessária para a implantação da escola, ou seja, para a materialização da lei de criação, a exemplo do projeto de lei de criação do ginásio estadual no município de Mairinque (Projeto de Lei n. 018/1958, de autoria dos deputados estaduais Francisco Scalamandré Sobrinho e Derville Alegretti). Em seu estudo, Arruda (2012) apresenta duas contrapartidas efetuadas pelo município:

[...] em 19/07/62, através da Lei Municipal No 92/62, o poder executivo foi autorizado a aplicar a verba orçamentária, no valor máximo de $\mathrm{Cr} \$$ 5.000.000,00 (cinco milhões de cruzeiros), na construção de um prédio para ginásio, em terreno do Governo Estadual, na cidade de Mairinque, de acordo com as orientações da Secretaria Estadual de Educação. (ARRUDA, 2012, p. 59).

Através da Lei Municipal N. 312/68, promulgada pelo então prefeito, Sr. João Chesine, foi autorizada a celebração de Convênio da Prefeitura Municipal de Mairinque com a Secretaria de Estado dos Negócios da Educação para a construção de um prédio destinado ao funcionamento do Ginásio Estadual Prof. a Altina Júlia de Oliveira, contribuindo o município até NC\$ 120.000,00 (cento e vinte mil cruzeiros novos), devendo a diferença ser coberta pelo Fundo Estadual de Construções Escolares. (ARRUDA, 2012, p. 74).

Com efeito, os municípios do interior que tinham condições para arcar com a contrapartida material imposta pelo Estado eram atendidos mais rapidamente, enquanto outros municípios mais desprovidos de recursos financeiros teriam que os conseguir para serem beneficiados com a escola ginasial.

Ainda se utilizando do caso do ginásio de Mairinque, elencamos uma terceira estratégia utilizada pelo Estado e Municípios para a instalação do ginásio estadual: o funcionamento do curso ginasial em grupos escolares:

A escola começou a funcionar em 6 de março de 1963. Quando de sua criação não havia prédio próprio para o funcionamento da escola, portanto, de 1962 a 1969 funcionou no prédio do Grupo Escolar Prof. Manoel Martins Villaça, na Av. Dr. Gaspar Ricardo Júnior, 172, Centro, em Mairinque, com a denominação de Ginásio Estadual de 
Mairinque. Suas classes se concentravam no período da tarde, funcionando, de manhã, as classes do curso primário.

[...]

Inicialmente, foram contratados em caráter emergencial, alguns professores da cidade, para o início das aulas, até que se procedesse a inscrição de professores. (ARRUDA, 2012, p. 70).

Tal mecanismo foi amplamente utilizado no governo de Jânio Quadros para o município da Capital, pois a instalação de seções dos ginásios oficiais existentes, que entrariam em atividade no período noturno em prédios de grupos escolares do município de São Paulo, se mostrava uma solução rápida para atender às pressões da população. Tal manobra não precisava de análise e/ou aprovação por parte da ALESP, cabendo apenas à Secretaria da Educação indicar quais bairros seriam atendidos.

Por certo, tal medida, somada aos ginásios oficiais criados nesse período, triplicou a oferta do ensino ginasial no município de São Paulo (vide tabela a seguir), porém, há que se destacar a precariedade das condições pelas quais se deu tal expansão, como bem assinala Spósito (2002).

Tabela 2 - Evolução das taxas de matrícula do ensino de nível médio no município de São Paulo (1940-1960)

\begin{tabular}{c|c|c|c}
\hline Ano & Matrículas & $\begin{array}{c}\text { \% de Matrículas em relação à } \\
\text { População }\end{array}$ & População \\
\hline 1940 & 41.961 & $3,2 \%$ & 1.317 .133 \\
\hline 1955 & 97.362 & $3,4 \%$ & 2.870 .258 \\
\hline 1957 & 115.097 & $3,6 \%$ & 3.193 .528 \\
\hline 1960 & 131.053 & $3,5 \%$ & 3.747 .964 \\
\hline
\end{tabular}

Fonte: SPOSITO (2002, p. 45) (fragmento).

Logo, a disputa no campo político que se desenha em torno da escola secundária ganha grande relevância, seja pelos vereadores e prefeitos ou pelos deputados e Poder Executivo estadual, que enfrentam pressões das populações locais sob pena de perda do prestígio político diante dos seus eleitores. Para Beisiegel: "Situado em posições decisivas para a realização das atribuições da Administração Pública no Ensino, o agente político utiliza as possibilidades de ação que essas posições lhe conferem: atendendo às reivindicações, consolida relações de compromisso, prestigia seus cabos eleitorais nos municípios e conquista votos." (1964, p. 192).

Muito diferente de se sensibilizar, os atores políticos que estão inseridos nesse campo têm em comum, a bem da verdade, um interesse único: o de se manter no poder. Para tanto, estar atento às demandas da população e respondê-las, efetivamente, torna-se uma condição vital de sobrevivência nesse campo. Nessas circunstâncias, as disputas existentes entre esses atores políticos eram intensas, pois todos buscavam concorrentemente angariar os proventos políticos das benfeitorias para os municípios, ou melhor, redutos políticos, pelos quais intercediam junto à ALESP e ao Poder Executivo estadual.

Especialmente nas ocasiões de eleição para o governo e para a Assembleia Legislativa do Estado de São Paulo no período de redemocratização, a capacidade de atuação dos agentes políticos em torno da expansão da rede de estabelecimentos de ensino secundário é decisiva, pois nessas eleições a criação de escolas secundárias, sobretudo os ginásios oficiais, aparece como recurso necessário à permanência no poder. 


\section{Considerações Finais}

Como buscamos argumentar neste artigo, foram diversas as estratégias utilizadas pelos municípios para a difusão do ensino secundário no Estado de São Paulo entre 1930 e 1964.

Durante a ditadura de Getúlio Vargas, os Interventores Federais, em âmbito paulista, tiveram um papel importante no aumento do número de ginásios oficiais; entretanto, tal expansão foi possível somente graças à contrapartida financeira e/ou material dos municípios que, pressionados pela demanda populacional, atendiam as exigências impostas pelo governo estadual. Dos 58 ginásios oficiais criados entre 1930 e 1947, 55 tiveram participação dos municípios para que sua instalação se efetivasse, ou seja, $95 \%$ do número total de estabelecimentos criados, traduzindo assim uma efetividade da política educacional proposta, atrelada ao anseio dos municípios que viam no ensino secundário uma necessidade premente, seja para seu desenvolvimento socioeconômico local ou para o privilegiamento do poder público local para atender um restrito grupo social, e com isso utilizar a escola como instrumento de diferenciação social. Entretanto, essa atuação dos municípios pode ser também interpretada como estratégia política para forçar o governo estadual a assumir a difusão do ensino secundário. No nosso entendimento essa hipótese se confirma, haja visto o prestígio que o Poder Executivo local acumulava a partir da inauguração de grandes obras de interesse público, em grande parte subvencionadas pelo Poder Executivo Estadual, e dentre elas, destacamos os ginásios oficiais. Diante disso, esse estudo revelou a importância que os municípios tiveram na expansão do ensino secundário no Estado de São Paulo e a necessidade de uma revisão da historiografia sobre o tema.

Igualmente, o que nos chamou a atenção é a instalação de ginásios oficiais em municípios que possuíam (e até hoje possuem) pouca representatividade socioeconômica perante o Estado, em detrimento a outros municípios com maior relevância e que por sua vez não foram contemplados à época com um estabelecimento de ensino secundário. Verificamos, pois, que já nesse período não haviam critérios específicos que norteavam um estudo prévio que determinasse a real necessidade da instalação (ou não) de um ginásio oficial em um determinado município; pelo contrário, o que ficou evidente é que a expansão dos ginásios oficiais durante a ditadura Vargas atendia prioritariamente a interesses políticos, de modo que um determinado grupo político - aliado ao Estado Novo -, se mantivesse no poder no âmbito municipal.

Com o período da redemocratização, constatamos que no Estado de São Paulo a expansão da rede de estabelecimentos de ensino secundário foi fortemente impulsionada pela ação dos deputados estaduais que viam na demanda crescente por esse nível de ensino uma grande oportunidade política. Mais uma vez, a adoção de uma análise prévia que permitisse indicar as reais necessidades dos municípios paulistas em torno dos ginásios oficiais cedeu lugar a critério nenhum, ou melhor, ao critério dos deputados estaduais que barganhavam melhorias nas cidades e, dentre elas a criação de escolas, em troca da manutenção e/ou ampliação de seus redutos eleitorais.

Ademais, nesse período, fica evidente a manutenção do mecanismo adotado à época dos interventores federais de contrapartida dos municípios no processo de estadualização do ensino secundário. Nesse aspecto, é válido destacar que tal metodização foi aplicada de maneira desigual, pois esta era imposta apenas aos municípios interioranos como condição para a obtenção do seu ginásio público.

A participação dos municípios na expansão da educação pública, no período de 1930 a 1964 exige investigações mais aprofundadas sobre as formas de articulação política estabelecida entre os prefeitos municipais e lideranças locais com os interventores e governadores. No período de 1930 a 1945 merecem ser examinados o Conselho Consultivo, o Departamento Administrativo e o Departamentos de Municipalidades. 
Já no período seguinte, a Alesp e a Secretaria da Educação são duas instituições que também poderiam ter seu acervo consultado para melhor compreendermos a interlocução de prefeitos, vereadores e outras lideranças políticas locais junto aos deputados estaduais e governadores que favoreceu a acelerada expansão dos ginásios oficiais ocorrida entre os anos de 1947 e 1963.

Nessa perspectiva, entendemos que dada a diversidade de maneiras que as prefeituras adotaram para conseguir ofertar o ensino secundário público em seus municípios, a imprensa escrita local é uma fonte primária que pode possibilitar uma compreensão bem mais ampla da participação inequívoca dos municípios e seus atores políticos no jogo político em torno da expansão do ensino secundário paulista.

Com efeito, não resta dúvida que a realização de estudos em torno da expansão do ensino secundário no Estado de São Paulo ocorrida em meados do século XX, revela-se um recurso potencial para compreendermos o papel que essa modalidade de ensino médio exerceu na sociedade em geral e como a demanda crescente por ela foi traduzida pelos poderes Executivo e Legislativo tanto em âmbito estadual quanto municipal. A temática analisada da perspectiva da história política põe em questão as disputas pela escola, as estratégias dos atores políticos para a criação e instalação de estabelecimentos escolares, bem como as múltiplas dimensões do poder implicadas na democratização do ensino público.

\section{Referências}

ALMEIDA, A. R. M. Entre o monumento idealizado e o realizado: a Escola Normal Livre Municipal de Sorocaba (1929 a 1967). Tese de Doutorado em Educação. Sorocaba: Uniso, 2015.

ANTONIO, M. R. S.; SOUZA, R. F. O Ginásio Municipal e a formação de professores: a Escola Normal Livre Mackenzie de Araraquara (1928 1939). In: SOUZA; R. F.; VALDEMARIN, V. T.; ZANCUL, M. C. S. (Org.). O Ginásio da Morada do Sol: história e memória da Escola Estadual Bento de Abreu de Araraquara. São Paulo: Editora Unesp, 2014, p. 92-103.

ARRUDA, A. L. M. M. Escola Altina Júlia: entre história e memórias. Dissertação de Mestrado em Educação. Sorocaba: Uniso, 2012.

BEISIEGEL, C. R. Ação política e expansão da rede escolar. Pesquisa e Planejamento, n. 8, São Paulo, 1964.

BOURdiEU, P. O campo político. Revista Brasileira de Ciência Política. Brasília. n. 5. p. 193-216, jan./jul. 2011.

BRASIL. Decreto n. 16.782-A, de 13 de janeiro de 1925. Estabelece o concurso da União para a diffusão do ensino primario, organiza o Departamento Nacional do Ensino, reforma o ensino secundario e o superior e dá outras providencias. Diário Oficial da União, 1925.

. Decreto-lei n. 4.244, de 09 de abril de 1942. Lei orgânica do ensino secundário. Diário Oficial da União, 1942.

Decreto-lei n. 8.530, de 2 de janeiro de 1946. Lei Orgânica do Ensino Normal. Diário Oficial da União, 1946. 
Dados estatísticos: eleições federais, estaduais, realizadas no Brasil em 1960, e em confronto com anteriores. Brasília: Imprensa Nacional. v. 5. 1963. Disponível em: http://bd.camara.leg.br/bd/handle/bdcamara/13037. Acesso feito em: 07 mai. 2017.

Sinopse Estatística do Ensino Médio 1964/1963. Ministério da Educação e Cultura. Serviço de Estatística da Educação e Cultura. 1964.

CARONE, E. A terceira república (1937-1945). São Paulo: Difel, 1976.

CODATO, A. N. Elites e instituições no Brasil: uma análise contextual do Estado Novo. Tese de Doutorado em Ciência Política. Campinas: Unicamp, 2008.

CODATO, A. N. A elite destituída: a classe política paulista nos anos trinta. In: João Ricardo de Castro Caldeira; Nilo Odalia. (Org.). História do Estado de São Paulo: a formação da unidade paulista. São Paulo: Editora UNESP; Imprensa Oficial; Arquivo Público do Estado, 2010, v. 2, p. 275-305.

CODATO, A. Os mecanismos institucionais da ditadura de 1937: uma análise das contradições do regime de Interventorias Federais nos estados. História, São Paulo, v. 32, n. 2, p. 189-208, jul./dez. 2013.

DINIZ, C. A. A educação secundária no interior paulista: estudo histórico sobre o Ginásio Estadual de Matão (1940-1965). Dissertação de Mestrado em Educação Escolar. Araraquara: Universidade Estadual Paulista "Júlio de Mesquita Filho" - Faculdade de Ciências e Letras de Araraquara, 2012.

DINIZ, C. A. A expansão dos ginásios oficiais e o campo político no estado de São Paulo (1947-1963). Tese de Doutorado em Educação. Marília: Universidade Estadual Paulista "Júlio de Mesquita Filho" - Faculdade de Filosofia e Ciências, 2017.

GONÇALVES, J. C. Poder local e educação na Primeira República: o primeiro ginásio público de Sorocaba. Dissertação de Mestrado em Educação. Sorocaba: Uniso, 2006.

INOUE, L. M. Entre livres e oficiais: a expansão do ensino normal em São Paulo (1927-1933). Tese de Doutorado em Educação. Marília: Universidade Estadual Paulista "Júlio de Mesquita Filho" - Faculdade de Filosofia e Ciências, 2015.

LABEGALINI, A. C. F. B. A formação de professores nos Institutos de Educação do Estado de São Paulo (1933-1975). Marília: Unimar, São Paulo: Arte \& Ciência, 2009.

LEAL, V. N. Coronelismo, enxada e voto. $5^{\text {a }}$ ed. São Paulo: Alfa-Omega, 1986.

LIMA Jr., O. B. (Org.). O sistema partidário brasileiro: diversidade e tendências, 1982-94. Rio de Janeiro: Editora Fundação Getúlio Vargas, 1997.

MICHEL, E. C. B. A criação e instalação do Ginásio Ciências e Letras de Sorocaba (SP). Dissertação de Mestrado em Educação. Sorocaba: Uniso, 2013. 
PAVINI, A. R. C. Um estudo sobre a criação das instituições escolares do município de Itápolis, São Paulo, na primeira metade do século XX. Dissertação de Mestrado em Educação Escolar. Araraquara: Universidade Estadual Paulista "Júlio de Mesquita Filho" Faculdade de Ciências e Letras de Araraquara, 2017.

SANDANO, W. A criação da Escola Normal Livre Municipal de Sorocaba. Série-Estudos. Campo Grande/MS: UCDB, 2009, n. 28, p. 75-87, jul./dez.

SÃO PAULO. Annuário do Ensino do Estado de São Paulo: 1935-1936. Publicação organizada pela Directoria Geral da Instrucção Pública por ordem do governo do Estado, São Paulo: Tip. Siqueira, [1937].

SÃO PAULO. Mostrar Clique ou toque aqui para inserir o texto. Publicação organizada pela Directoria Geral da Instrucção Pública por ordem do governo do Estado, São Paulo: Tip.

Siqueira, [1938].

SÃO PAULO. Lei n. 2.269, de 31 de dezembro de 1927. Reforma a Instrucção Publica do Estado. Diário Official do Estado de São Paulo, 1927.

. Decreto n. 5.408, de 4 de março de 1932. Crêa um ginásio em Araraquara. Diário Oficial do Estado de São Paulo, 1932a.

Decreto n. 5.424, de 5 de março de 1932. Cria um Ginásio em Itú. Diário Oficial do Estado de São Paulo, 1932b.

Decreto n. 5.429, de 5 de março de 1932. Dispõe sobre a instalação do Ginasio de Taubaté. Diário Oficial do Estado de São Paulo, 1932c.

Decreto n. 5.430, de 5 de março de 1932. Crêa um Ginásio em Catanduva. Diário Oficial do Estado de São Paulo, 1932d.

. Decreto n. 5.494, de 29 de abril de 1932. Crêa um Ginasio em Rio Preto. Diário Oficial do Estado de São Paulo, 1932e.

. Decreto n. 5.884, de 21 de abril de 1933. Código de Educação do Estado de São Paulo. Diário Oficial do Estado de São Paulo, 1933.

Decreto n. 7.051, de 3 de abril de 1935. Cria um Gymnasio Official em São João do Bôa Vista. Diário Oficial do Estado de São Paulo, 1935a.

. Decreto n. 7.105, de 10 de abril de 1935. Cria um Gymanasio Official em Itápolis. Diário Oficial do Estado de São Paulo, 1935 b.

. Decreto n. 10.334, de 21 de junho de 1939. Crea um Ginasio Estadual em Caçapava. Diário Oficial do Estado de São Paulo, 1939a.

Decreto n. 10.709, de 21 de novembro de 1939. Crêa um Ginásio Estadual em Itapira. Diário Oficial do Estado de São Paulo, 1939b. 
. Decreto-lei n. 14.562, de 26 de fevereiro de 1945. Dispõe sôbre a criação do Ginásio Estadual em São José dos Campos. Diário Oficial do Estado de São Paulo, 1945a.

Decreto-lei n. 14.786, de 13 de junho de 1945. Dispõe sobre a criação de um Ginásio Estadual em Jacareí. Diário Oficial do Estado de São Paulo, 1945b.

Decreto-lei n. 15.170, 24 de outubro de 1945. Dispõe sobre criação de um Ginásio Estadual em Pindamonhangaba. Diário Oficial do Estado de São Paulo, 1945c.

Decreto n. 15.174, de 24 de outubro de 1945. Dispõe sobre criação de um Ginásio Estadual em Moji Mirim. Diário Oficial do Estado de São Paulo, 1945d.

. Decreto-lei n. 15.235, de 28 de novembro de 1945. Dispõe sobre organização no ensino secundário. Diário Oficial do Estado de São Paulo, $1945 \mathrm{e}$.

Decreto-lei n. 16.076, de 12 de setembro de 1946. Dispõe sobre criação de uma Escola Normal e Ginásio Estadual em Cruzeiro. Diário Oficial do Estado de São Paulo, 1946a.

Decreto-lei n. 16.668, de 31 de dezembro de 1946. Dispõe sobre criação de Ginásio Estadual em Igarapava. Diário Oficial do Estado de São Paulo, 1946 b.

. Decreto-lei n. 16.871, de 10 de fevereiro de 1947. Dispõe sobre a criação de um Ginásio Estadual. Diário Oficial do Estado de São Paulo, 1947. 1951a.

Projeto de Lei n. 478, de 17 de maio de 1951. Assembleia Legislativa de São Paulo. $1951 b$.

Projeto de Lei n. 628, de 20 de junho de 1951. Assembleia Legislativa de São Paulo.

Projeto de Lei n. 1.366, de 13 de dezembro de 1951. Assembleia Legislativa de São Paulo. 1951c. $\overline{1952 \mathrm{a} .}$ $1952 b$.

Projeto de Lei n. 573, de 2 de julho de 1952. Assembleia Legislativa de São Paulo.

Projeto de Lei n. 1.081, de 23 de setembro de 1952. Assembleia Legislativa de São Paulo. 1952c.

. Projeto de Lei n. 1.492, de 09 de dezembro de 1952. Assembleia Legislativa de São Paulo. 1952d. 1956a.

Projeto de Lei n. 670, de 1 de outubro de 1956. Assembleia Legislativa de São Paulo.

Projeto de Lei n. 937, de 28 de novembro de 1956. Assembleia Legislativa de São Paulo. 1956b. 
1957a.

Projeto de Lei n. 285, de 2 de maio de 1957. Assembleia Legislativa de São Paulo.

Projeto de Lei n. 814, de 24 de julho de 1957. Assembleia Legislativa de São Paulo. $1957 b$.

Projeto de Lei n. 1.448, de 23 de setembro de 1957. Assembleia Legislativa de São Paulo. 1957e.

SCHWARTZMAN, S.; BOMENY, H. M. B.; COSTA, V. M. R. Tempos de Capanema. São Paulo: Paz e Terra: Fundação Getúlio Vargas, 2000.

SOUZA, M. C. C. Federalismo no Brasil: aspectos político-institucionais (1930-1964). Revista Brasileira de Ciências Sociais, v. 21, n. 61, p. 7-40, jun. 2006.

SOUZA, R. F. História da Organização do Trabalho Escolar e do Currículo no Século XX. São Paulo: Cortez Editora, 2008.

SOUZA, R. F. Fernando de Azevedo e a reconstrução do sistema educacional de São Paulo em 1933: sentidos e alcances de um projeto de reforma. In: MIGUEL, M. E. B.; VIDAL, D. G.; ARAUJO, J. C. S. (Org.). As manifestações da Escola Nova no Brasil (1920-1946). Uberlândia/Campinas: EDUFU/Autores Associados, 2011, p. 337-361.

SOUZA, R. F. Do Araraquara College à Escola Estadual Bento de Abreu. In: SOUZA; R. F.; VALDEMARIN, V. T.; ZANCUL, M. C. S.. (Org.). O Ginásio da Morada do Sol: história e memória da Escola Estadual Bento de Abreu de Araraquara. São Paulo: Editora Unesp, 2014, p. 54-91.

SOUZA, Rosa Fátima. A atuação dos municípios na difusão da instrução primária no estado de São Paulo (Campinas, 1889 - 1910). In: GONÇALVES NETO, Wenceslau; CARVALHO, Carlos Henrique de (Org.). Ação municipal e educação na Primeira República no Brasil. Belo Horizonte: Mazza Edições, 2015, p. 101 - 128.

SOUZA, R. F.; DINIZ, C. A. A articulação entre Estado e municípios na expansão do ensino secundário no estado de São Paulo (1930-1947). In: DALLABRIDA, Norberto; SOUZA, Rosa Fátima. (Org.). Entre o ginásio de elite e o colégio popular: estudos sobre o ensino secundário no Brasil (1931 - 1961). Uberlândia: EDUFU, 2014, p. 213-251 (Série Novas Investigações, v. 5).

SOUZA, R. F.; et al. Fontes para a história política da educação brasileira. In: IX Congresso Brasileiro de História da Educação, 2017, João Pessoa - PB. Caderno de Resumos. IX Congresso Brasileiro de História da Educação. João Pessoa: UFPB, 2017. p. 790.

SPOSITO, M. P. O Povo vai à escola: A luta popular pela expansão do ensino público em São Paulo. São Paulo: Loyola, 2002. (Coleção Educação Popular, n. 2).

TEIXEIRA, W. S. Educação e poder local: a formação do sistema de ensino em Franca e os limites da cidadania. (1889 - 1928). Dissertação de Mestrado em História. Franca: Universidade Estadual Paulista "Júlio de Mesquita Filho" - Faculdade de Ciências Humanas e Sociais, 2000. 